\title{
Igbo Cosmology in Chinua Achebe's Arrow of God: An Evaluative Analysis
}

\author{
Marcel Ikechukwu Sunday Onyibor \\ Department of General Studies, School of Sciences, Federal University of Technology Akure, Akure, Nigeria \\ Email: misonyibor@futa.edu.ng, marcelifeanyi@yahoo.com
}

Received 3 December 2015; accepted 26 February 2016; published 29 February 2016

Copyright (C) 2016 by author and Scientific Research Publishing Inc.

This work is licensed under the Creative Commons Attribution International License (CC BY). http://creativecommons.org/licenses/by/4.0/

(c) (i) Open Access

\section{Abstract}

The death, burial, and funeral of African literary icon professor Chinua Achebe (1930-2013) and the fifty years anniversary of the publication of Arrow of God (AG) have led to fresh interest in the works and times of this great African literary giant. Though many books and journal articles have already been written on various themes of his work, one must not forget that Achebe wrote most of his fictional novels from Igbo traditional background. Our interest in the present endeavour is to investigate how Arrow of God recreated the Igbo traditional cosmology in various plots and characters in the novel, as well as how relevant these are to the contemporary Igbo and black Africa in general. Our methodology lies in the thematic discussion and interpretation of the plots and characters in the novel. The study is concluded on the note that Achebe exposed inevitable consequences of the situation when those in position of power and authority forget the derivative source of their power (the people) and rather cling to individual and personal aggrandizement. This will definitely bring them down from grace to grass like the chief priest of Ulu deity in Arrow of God. The novel also reveals that there is indeed a great repository of oral pre-literate tradition which our forebears have left behind for us to transmit to the coming generation as well as us as moral-social pedestal and foundation for engineering new paradigm structures for internally motivated African development.

\section{Keywords}

Igbo, Cosmology, Arrow of God, Ezeulu, Umuaro, Ulu Deity

\section{Introduction}

Scholars have over the years, subjected Chinua Achebe's Arrow of God to critical analysis. And till today, the work has continued to receive scholarly attention. Hence, a new article on the subject is bound to repeat some of the previous arguments. However, a critical analysis of this novel will reveal that much is left to be on the book 
bearing in mind that Achebe situated Arrow of God (AG) historically within the colonial Igbo Nigeria with the intention of consciously restoring a sense of humanity and history to post colonial Africa, as well as exposing how Africans perceived the arrival of the colonizing order. In fact Achebe describes his novels "'as recreation of history of Africa (Igbo) in fictional term" and what he recreates in Opata's words are human deeds and experiences that lie in the African past.”

Many scholars like Abiola (1971), Margaret Lawrence (1968), Povey (1971), Echeruo (1975), Okonkwo (1996), Umezinwa (1996) and Ola (1996 \& 2004) have written on the novel pointing out Achebe's mastery of the history and culture of the people he tried to portray. Ola (1996: p. 219) specifically remarks that,

Arrow of God is Achebe's master piece; Ezeulu is his most successful delineated hero and the most impressive. The work shows Achebe's genius at its most ironic, most challenging and most rebellious. The second being that Ezeulu is Achebe's best realized hero within the context of his early village novels, where character and history are inseparable.

Thus, Echeruo (1975: p. 155) summarizes its merits in these words "Arrow of God, a much denser and more technically sophisticated novel than the two earlier novels, tells three stories in one integrated style: the trial of Ezeulu, the disintegration of the indigenous political and religious order in Umuaro, and the establishment of British rule and Christian religion.”

Our interest in this paper is to analyze the extent to which Achebe used the story of the trial of Ezeulu, the disintegration of the indigenous political and religious order in Umuaro and the establishment of British cum Christian religion in AG to expose the Igbo traditional cosmology which is the basis of indigenous Igbo political and religious attitude to life as well as its relevance to the contemporary Igbo. Achebe also in AG attempted indigenous portrayal and criticism of the culture and institution of the denigrated Igbo people with the intention of highlighting both its strengths and weaknesses. He does this by building arguments and persuasive rhetoric around the life and career of Ezeulu, the chief priest of Ulu deity in Umuaro (Alumona, 2003: p. 62). Before delving into the main body of this article, we shall briefly discuss the traditional Igbo cosmology vis-a vis its portrayal by Achebe in Arrow of God.

For the purpose of this study, the term Igbo is used as a double signifier. First as one of the three major ethnic groups in Nigeria inhabiting the territory of the South eastern Nigeria located at both banks of the River Niger from which Nigeria derives her name. Basden (1938) describes them "as one of the largest in the whole of Africa," while Okafor (2004) put their population figure at "about twenty-five million" what he believes is "larger than those of Norway, Sweden and Denmark combined." Secondly, it is used to designate the traditional language of this group called Igbo which belongs to the Sudanic linguistic group of kwa division, (Onwuejeogwu1981). The language is characterized by its tonality, the monosyllabic root-words and absence of in-flexional endings (Nwoye, 2011: p. 305). The Igbo traditional society set-up is historically egalitarian in structure and democratic in organization. Green (1964) states: "the Igbo have no hierarchy of powers arising from a broad democratic basis through ascending levels to one central peak... Rather, Ibo democracy, unlike the English, works through a number of juxtaposed groups and a system of balances rather than on a unitary hierarchy principle."

Hence, the traditional Igbo socio-political organization is the town level made up of various villages interlinked horizontally with its neighbours, by the social bonds of inter-marriage that is based on the principle of exogamy. This encourages equality, communalism and egalitarianism at all levels, while the title associations like ozo title groups etc promotes individualism with prestige, power and authority attached to solid personal and material achievement. Every town has a market held usually every four or eight days, which act as a unifying place where people gather to exchange goods and services as well as socialize.

Cosmology as applied in this work means a philosophical theory which studies the material world with regards to its origin, structure and ultimate end. There are numerous cosmological theories in philosophy each built up on a given cultural and religious background. Thus, Onyibor (2012: p. 36) remarks that "the concept of the world whether sensible or supra-sensible held by a people in a given culture has a vital influence on their attitude to and evaluation of life and death.” Okafor (1992: p. 13) equally asserts that "cosmological and metaphysical ideas determine the basic notions underlying our cultural, religious and social activity. In fact these notions, necessarily though, sometimes covertly shape our behavior and thus guide our actions.”

Cosmology therefore, is basically anchored on perception vis-a-vis assumptions or beliefs. Therefore, Igbo perception of their world determines their attitude and actions. Uchendu (1965) alludes that Igbo cosmological 
perception "is not only their theory of the origin and character of the universe. It also contains prescription for the societal moral ethos, which dictates rules governing both inter personal relationships as well as man's relationship to his environment and to the supra sensible. Moreover, in it is to be found the explanations for the family background patterns of Igbo.” Animalu (1990) refers to it as a people's way of organizing their activities which explains the how and why of daily existence. It is a product of experiences so pregnant with drama that such experiences give rise to symbols or totems of some sort. The symbols give rise to thought or creative intelligence (ako-na-uche) and creative intelligence give rise in turn, to the customs and codes of the society, which are so internalized from childhood onwards that they go unquestioned as a way of life. Thus, a cultural group such as the Igbo is able from their cosmology, to explain reality, life and the human environment, predict space-time events, and finally exert control over them. This way, the force of Igbo traditional religion just like any other religion, rest with the cosmology which undergirds it (Ejizu, 1987).

Igbo traditional religion which is anthropocentric equally provides principles on which its cosmology is based. Its logic is derived from this intrinsic value for human life and the network of connectivity and interrelatedness linking every aspect of cosmic order. However, enhancement of life remains the most vital consideration in the entire perception and scheme of activities of man which is often performed through ritual sacrifice revealed in divination and other means. Thus, one may sum up the fundamentals of Igbo traditional cosmology to consist of belief in the Supreme Being, Chukwu/Chinaeke, that created the world both visible and invisible, belief in the reality of the ancestors and existence of spirits both good and evil, belief in duality or phenomenon of pairing, belief in reincarnation "ilo uwa" and choice of destiny. Hence, Uchendu (1965: p. 20) reiterates the above beliefs when he states that,

... the Igbo world is a world peopled by the visible and invisible forces, by the living, the dead and those unborn. It is a world in which all these interact, affecting and modifying behavior, a world that is delicately balanced between opposing forces, each motivated by its self-interest, a world whose survival demands some form of cooperation among its members, although that cooperation may be minimal and even hostile in character. It is a world in which others can be manipulated for the sake of the individual status advancement, the goal of Igbo life.

In fact, the principle of dualism and pairing is deep-rooted in all aspects of Igbo life, and its natural consequence is the existence of another basic principle, the principle of balance. These two principles have seriously affected their attitude to life and relationship to their gods and to each other. Achebe has severally reiterated the centrality of the notion of duality and balance in Igbo thought and life. He often states this in form of idiomatic expression such as "wherever something stands, something else will stand beside it.” Hence, their belief is anchored on firm ontological foundation that whatever exists, something else exists beside it. As such they always strive to maintain the middle course in life, being careful not to disturb the equilibrium of their spiritual and physical existence. The above principle also implies that both the feminine and masculine gender complement each other in the Igbo traditional society. As Achebe put it elsewhere "the pre-colonial Igbo life was highly materialistic society. But at the same time a strong spiritual dimension controlled its materialistic aspects. And the culture was successful because there was a complementary balance between the two, the materialistic dimension of Igbo life being related to its masculine principle and its spiritual dimension being related to its feminine principle."

The above reflects the traditional Igbo cosmological belief that was in place before the British colonization and the interference with Igbo land and culture. We shall thematically delve into the interpretation of Chinua Achebe's description of the above belief system in AG which he weaved around the lives, characters, and institution of Ulu deity, its chief priest Ezeulu and the entire Umuaro community.

\section{Igbo Cosmology in Achebe's Arrow of God}

The first important aspects of priestly function in Igbo traditional society, which Achebe exposed in Ezeulu in the first chapter of AG is the priestly role of keeping the community alert to changes in nature. This was demonstrated in Ezeulu's priestly function as watchman to see and announce the new moon to the community. This duty is so important and ritualized to the extent that even his Obi was built to enable him perform this role without hitches. 
His Obi was built differently from other men's huts. There was the usual long threshold in front but also a shorter one on the right as you entered. The eaves on this additional entrance were cut back so that sitting on the floor; Ezeulu could watch that part of the sky where the moon had its door. (319).

Thus, he aids the community in keeping an“eye” on nature to monitor the passing and changing seasons, as well as linking the people to the universe "uwa” which the moon "onwa” symbolizes. In Ezeulu's priestly office, his community has ritualized and institutionalized its concern with the regulation of its cosmos. Hence Achebe describes a physical relationship in the life and functions of Ezeulu which is based on observed perceptible abstract principles of nature. Supporing this assertion Kalu (2004: p. 101) comments:

The people see the approach of the seasons through the moon. This arrangement constitutes one aspects of Ezeulu's bridging function between the people and their world. He becomes one of the tools which Umuaro uses in its attempts to live harmoniously with nature. It is an important manifestation of his priestly responsibility.

In AG Achebe also widely used Ezeulu, to describe how Igbo traditional religion, politics, philosophy and art were combined to give meaning to the Igbo traditional abstract notion of dualism, a concept and principle central to Igbo cosmology and widely applied by Achebe in his novels. Ezeulu' priestly functions especially in initiating plans for the security of Umuaro combined with his attitude to life and understanding of his community thought and lore was used to give insight into the workings of Igbo traditional society. In the performance of his duties to the Ulu deity and Umuaro, he exhibits a strong desire to preserve both for posterity. Ulu, though instituted by the people in a time of crisis and insecurity, later became their god of protection and symbolized the traditional Igbo emphasis on the community well being and security. Thus, Ezeulu's desire and inclination to preserve this tradition and culture becomes the core of his portrayal of dualism. This Achebe exposed in the event of festival of the first pumpkin leaves, when he states in chapter seven:

He wore smoked raffia which descended from his waist to the knee. The left half of his body from his forehead to toe was painted with white chalk. Around his head was a leather band from which an eagle feather pointed backwards. On his right hand carried Nneofor, the mother of all staff of authority in Umuaro.

The half painted part of his body symbolize the priest ability to stand and relate between the visible and invisible realities of his community, thus reaffirming for them the harmonious and copenetrative existence of the two realities of the traditional Igbo world. Hence, it is a concrete existential way of bringing together the people's view of duality as it makes that which is intangible visible. This embodies the traditional Igbo perception of his world.

Kalu's (102) comments on this are very instructive when he reiterates that:

it is significant that this symbol is manifested during the festival of the first pumpkin leaves, the first food related item to be harvested in the year. The harmonious society works together to produce life-giving food. The abundant green leaves carried by women symbolize life and good health, continuity of the group is reaffirmed and reassured.

The priest is both an intermediary and representation of the community rather than the priest as an individual. This portrays the Igbo concern for the expression of community will over that of the individual. Achebe exposed this aspect of Igbo thought when he narrates Ezeulu's attempt to attach too much importance to himself and Ulu deity. Achebe uses the individualistic tendency in Ezeulu to do an in-depth exploration of Igbo maintenance of dualism in their thought and praxis. For Achebe, the harmonious integration of the traditional society and the individual's place in that society were reflected in the relationship that existed between the society in its entirety and the deity or deities to which that society subscribed. In Igbo world propitiatory rites become an essential ritual in the maintenance of this cosmic balance. This is portrayed in the argument between Ezeulu and the elders of Umuaro in the attempt to resolve the impasse in the ritual of naming of the new yam festival as the custom demands in chapter eighteen. As Ononyi Nnanyelugo, one of the ten most titled elders and leaders of Umuaro says: "we have asked Ezeulu what was Ulu's grievance and he has told us. Our concern now should be how to appease him: let us ask Ezeulu to go back and tell the deity that we have heard his grievance and we are prepared to make amends. Every offence has its sacrifice from a few cowries to a cow or human being." (534) 
Ezeulu's response betrayed his intention to do his will rather than that of the deity: "if you ask me to go back to Ulu I shall do so. But I must warn you that a god who demands the sacrifice of a chick might raise it to a goat if you went a second time" (534).

The above response from a priest who should be more concerned about the well-being of his community becomes suspicious. Hence, Ononyi Nnanyelugo’s subsequent response becomes more direct and instructive: “Although I am not the priest of Ulu, I can say that the deity does not want Umuaro to perish. We call him the saver" (534). He further reminds Ezeulu his duties and responsibility to Umuaro, "therefore, you must find a way out, Ezeulu... it is you, Ezeulu, to save our harvest” (535).

The most important aspect of the long argument between Ezeulu and leaders of Umuaro lies in their advice to the chief priest to do the needful. This is because of their belief that they possess the inherent right to absolve him of any repercussion that may result from his obeying their collective wish as a result of which Ulu deity was created in the first instance. This was summed up in the words of Anichebe Udeozo when, he says:

Yes, we are Umuaro. Therefore listen to what I am going to say, Umuaro is now asking you to go and eat those remaining yams today and name the day of the next harvest, do you hear me well? I said go and eat those remaining yams today, not tomorrow and if Ulu says we have committed an abomination let it be on the head of the ten of us here. You will be free because we have set you to it, and the person who sets a child to catch a shrew should also find him water to wash the odour from his hand. We shall find you the water. (535)

Achebe portrays the complex issue of the personal motive and the will of the deity in such a way that, given the traditional Igbo cultural milieu and world view; Ezeulu stands convicted of abuse of power, arrogating the power of Ulu to himself which results in Achebe's remark in chapter nineteen at the end of the novel that "only Umuaro and its leaders saw the final outcome. To them, the issue was simple, their god had taken sides with them against his headstrong and ambitious priest and thus upheld the wisdom of the ancestors that no man however great, was greater than his people; that no one ever won judgment against his clan” (536). Reiterating the Igbo religious worldview that deities are human creation and with Ulu belonging to this category, the community that instituted it has the right to change whatever aspect that does not fit into their life style, as a result of changing times. Hence, Ezeulu's various attempts to asserts his authority over the six amalgamated villages of Umuaro and their various deities by means of Ulu's oracle power always met opposition in the person of Nwaka and Ezeidemili. Thus, Ezeulu's earlier rhetorical question to his alter ego Akuebue in chapter twelve reveals his intention: "who tells the clan what to say? What does the clan know?" (454).

The above passage reveals the extent of Ezeulu's arrogance. He assumes that he knows better than the clan what is best for them, therefore, the clan should, as a matter of necessity, take his words of advice. Ezeulu fails to balance the two critical role of priest in traditional Igbo community. He seems to have forgotten that as an intermediary for the people and as well as being the servant of the deity, he must always maintain balance between the two, and need not be at variance, for the simple reason that the deity, apart from being instituted by them, belongs to and is expected to function for the welfare of the people. Ezeulu allowed his human side to rule his sense of critical constructive judgement as Achebe in the early part of chapter eighteen reports that: "after a long period of silent preparation, Ezeulu finally revealed what he had been planning all along, that he intended to hit Umuaro at its most vulnerable point - the feast of the new yam” (527). There was no indication that this was the deity's decision because Ezeulu's action as he rightly thought and calculated was meant to mortally wound, if not destroy the clan, for as Ezeulu remarks: "the punishment was not for now alone but for all time. It would afflict Umuaro like an Ogulu-aro disease which counts a year and returns to its victim” (527). Such a situation would have made Ulu impotent by destroying the Umuaro's dependence on it. Hence, no other resolution of the conflict would have sufficed except the deity himself unmasking the man behind the priest and making him irrelevant in the "eyes" of the community.

Achebe, however, remarks that "if this was so then Ulu had chosen a dangerous time to uphold that truth for in destroying his priest he had also brought disaster on himself” (527). At this juncture we agree with, Ojinmah (2004) remarks that:

Ulu's decision to self-destruct by destroying his priest was consistent with the original purpose of its creation which is to protect the clan. In a world in which it was progressively becoming redundant, being likened to a dead god, it was proper that in its death throes the deity should in the face of such unimaginable recurrent calamity as faced by Umuaro, raise its demise to the stature of a ritual of passage (234). 
The death of one of Ezeulu's son, Obika, becomes an appropriate propitiation in this ritual of passage in conformity with the norm of its institutionalization. Bearing in mind the earlier remark of Ononyi Nnanyelugo in chapter eighteen about sacrifice of appeasement, "every offence has its sacrifice, from a few cowries to a cow or a human being" (534). Moreover, it would be recalled that at Ulu's creation and institutionalization, Umuaro had sacrificed one of their own as appropriate to the potency of the medicine that became the deity. The god in reciprocation efficaciously carried out its functions as Achebe in chapter two notes: "from that day, they were never beaten by an enemy" (334).

Umuaro being faced once more by a threat of similar magnitude and an impending calamity that had the potential of wiping out the entire clan, it is expected that Ulu should rise to the challenge. But this time the resolution of the foreboding disaster requires the death of the deity itself. Hence, this as in the initial creation of the deity requires a propitiatory sacrifice that is commensurate with the "task" the deity has to perform of saving the clan. To cushion its demise as in its creation in accordance with the people's religious custom requires an appropriate sacrifice. Obika's death fulfils this ritual function, but more than this, it represents the most proportional resolution that conclusively incorporates Ezeulu without leaving ends, the final resolution has to leave the existence of Umuaro uncompromised. Thus, Ulu has to vindicate the original Umuaro's belief and trust in it, even at the risk of its own destruction or downfall of its headstrong priest, Ezeulu. Arguably, Achebe uses the Arrow of God to also expose the scope and nature of power and authority in Igbo traditional society.

Ola (1996: p. 96) corroborating the above remarks that," the tragedy emanating from the above is that of inability of a people albeit a great people, to understand its own savior and not that of an angry god joining forces with its devotees to destroy a headstrong chief priest". Her assessment was based on the fact that "Ezeulu was variously portrayed in the novel as a man of extraordinary strength of mind. Everything he did was thoroughly calculated, based on policy rather than on blind impulse. These are some of the special features of his mental constitution which made him so unmanageable. He dared to posit his individual will and personal yearnings against the long cherished social dictates laid down by Umuaro to suppress such yearnings. So he is also the lonely rebel, the injured ruler and arrogant autocrat in one". The critic who concentrates on the destruction of Ezeulu to the exclusion of Umuaro, its gods and its tradition misses the central imperative of the novel, which Echeruo (1975: p. 155) summed up as being "about the death throes of an age, and signals the turning-point in the history of a people". Such a critic would have made the same mistake of the Umuaro people in not recognizing the sanctity and precariousness of Ezeulu's office, which the title of the novel underscores (Ola, 2004: p. 218). She further remarks that

at the height of his disagreement with his people, the hero saw the harvest and the eating of the new yams, which precedes it as a precious opportunity to punish them for not trying to obtain his release when he was imprisoned by the white man. By refusing to consume the ritual yams faster than allowed, he was indeed upholding a tradition with very complex ramifications. Without consuming the five tubers of yam, the harvest festival which is also Ulu's most prized ceremony and the period of his highest glory and appreciation by the community, cannot take place. The destiny of the community, the harvesting of their crops and the appreciation of the deity for its care and protection over his people are all tragically interwoven. Unknown to the chief priest, therefore, he was punishing Ulu through the people of Umuaro. He was in his search for revenge, stepping on the toes of his god who in his less than divine aspect enjoyed the annual tribute of a grateful people.

She concludes that:

Ezeulu was only being human yet this episode remains the one instance in his priestly role when he allowed himself to be swayed by personal rather than rigorous objective considerations. He was not in his high historic office permitted to exact punishment by depriving a capricious deity his special annual feast. It almost required him to be more than human. He gave in to his hubris and failed the ultimate test by succumbing to the human (Ola, 2004: p. 211).

Thus, Ezeulu's traditional role as the chief priest of Ulu, Umuaro's god of protection is to always march in front of the people leading and confronting all threats to their wellbeing. He must always find ways to maintain balance between Ulu's instructions and his personal will. This he fails to do at the instance when it was needed most; hence the community accused him of abuse of the power vested in him. However, one must note that although Ezeulu was portrayed by Achebe in the early part of the novel to be open to change, he is ultimately in- 
terested in preserving the religious order of his community to which he is the custodian. Judging from the above AG should be viewed AG as an attempt by Achebe to expose and criticize the cultural and religious institutions of indigenous, disintegrated and under reported people of Africa, with a view to highlighting both its strength and weakness. This is achieved by building arguments and persuasive rhetoric around the lives and characters of Ezeulu and some dominant individuals in Umuaro.

Achebe often-times make his character question the rationale behind certain beliefs and practices. Also through this style he portrays the traditional Igbo community as having had a critical disposition in their culture necessary for philosophical reflection as seen in other apparently civilized cultures of the world. He also portrayed Igbo culture as a "shame" culture where visible success is revered and individuals and groups can go to any length to achieve it. He also projects Igbo society as a tribe where family cohesion and lifelong material bond and dependence are cherished and treasured values, as well as a community that revered maternity as an important aspect of the community life.

Another important aspect of Igbo cosmology discussed by Achebe in AG is Ikenga Cult, a sculpture horned Alusi deity maintained and kept or owned by men and occasionally women of high reputation and integrity in the community. It is an embodiment of the owner's Chi (personal god), his Ndichie (ancestors), aka Ikenga (right hand), and Ike (power). It is spiritually activated through consecrative prayer and sacrifice. Ndi Igbo hold it in high esteem as a personal god of human endeavour, achievement, success and victory. Ikenga is grounded in the Igbo belief that the power for a man to accomplish things is in his right hand. It also determines their achievement and failures, industry, farming, creativity and skill. In some Igbo cultural areas, it is celebrated every year with an annual Ikenga festival. It is believed by its owner to bring wealth and fortune as well as protection. It is mostly found in shrines of individuals, diviners and community tutelary cults as representatives of age grade, kindred and communities. Willy Umezinwa (1996: pp. 124-136) describe it "as the curve of survival". Ifemesia (1979: p. 34) reports that the wooden cast of Ikenga is "the Igbo symbol of a man's strength and drive for enterprise and achievement”.

Achebe introduces discussion on Ikenga in chapter one of AG when he describe Ezeulu's Ikenga as being about as tall as a man's forearm, its animal horn as long as the rest of its human body" (319). However it was from the mouth of Captain Winterbottom in chapter three that Achebe analyzes the cosmo-ontological symbolism of Ikenga, when he describes it "as the most important fetish in Igbo man's arsenal, so to speak, it represents his ancestors to whom he must make a daily sacrifice. When he dies it is split in two one half is buried with him and the other half is thrown away" (343). Thus, Umezinwa (1996: p. 131) reiterates "as a matter of fact Ikenga is a plastic synthesis on dynamic movement or the desire of man to survive through individual creativity and personal growth. Its aesthetic definition is the modulation of rectilinearity with curve linearity in order to prove that growth is the nature of man endowed with vertical horns". While, Agada (2008) describes it as having aggressive up thrust with curve linear horns. These curved horns signify strength, defiance and self-reliance”. Umezinwa further states that "Ikenga is a modulated radius of an existential circle in which man stands at the centre while exercising a controlling influence" (131). It is therefore not only the affirmation of man's vertical erection in space in Igbo world but also "a plastic declaration on the importance of work symbolized by the arm". Hence, one cannot comprehend the folly of Akukalia's indiscretion in AG in chapter two when "he rushes after Ebo, went into the obi, took the Ikenga from his shrine, rushed outside again and while everyone stood aghast split it in two" (356). Of course the offender paid the supreme price for his acts of indiscretion.

In fact, it is an abomination of the highest order in Igbo cultural milieu for one's Ikenga to be split while he is still life, so it is not surprising that Ebo had to appease his Chi and his ancestors by gunning down the offender Akukalia. This is because Ikenga is a symbol of power and strength of a special kind. Ani Casmir et al. (2014) describe it as the power of synergy that results from a rarified individual embodiment of societal moral and metaphysical values in the indigenous Igbo world". Hence, we maintain that Ikenga symbolize for the Igbo man perseverance, self control, bravery and hard work, which guided and still guides his aspirations and endeavours in life. Ezeulu being a perfect product of Ikenga civilization to use Umezinwa's expression of this phenomenon, his excessive arrogance, self-will and independence of character is a of a slur on the tenet of Igbo culture, which requires its members to manifest (ako-na-uche) wisdom, creative ingenuity, flexibility and suppleness.

\section{Summary and Conclusion}

One may sum up the discussion in this paper by reiterating that the traditional Igbo cosmo-ontology on life and their attitude to life was highly well integrated based upon the maintenance of balance and avoidance of ex- 
tremes. Of course, this does not mean that their society was a perfect one; it had its weakness too, like the killing of twins and human sacrifice. In fact, it was these weaknesses that precipitated its disintegration by the coming of the colonizing order. However, it could be rightly maintained that the pre-colonial Igbo society succeeded to some extent in harmonizing his/her life in accordance with the basic factors for conducting healthy and meaningful life. Hence Achebe in AG applied some of these principles like the one which does not allow individual to win confrontation between him and either his "chi” or the community. Individuals are usually socialized to achieve their best within the community norms and ethos that guarantee their welfare and protection.

Secondly, Achebe in AG achieved what some scholars refer to as unity of festival "drama” by interpreting Igbo cosmology through descriptive images of customs and traditions of imaginary Umuaro community.

Thirdly, in none of the known scholarly works of fiction by writers of Igbo extraction has the Igbo traditional cosmology been as exhaustively discussed as in Achebe's AG. His portrayal of Ezeulu, his chief character, shows Achebe understanding of Igbo culture and thought, paralleling him to the traditional elders of the Igbo community. His hermeneutical exegesis of Igbo life places him among the critical thinkers and interpreters of Igbo tradition and custom. In fact, Achebe writes in "Morning Yet on Creation Day" that the writer cannot expect to be excluded from the task of re-education and re-generation that must be done. In fact, he should march right in front for he is after all, as Ezekiel Mphalele states in his "African Image," the sensitive point of his community”. The above assertion makes his role similar to Ezeulu, the chief priest of Umuaro's god of protection "Ulu" whose function is to march in front of the people leading and confronting all threats to their communal existence. Unlike Ezeulu the writer has to be able to find ways of striking a balance between his personal inclination and the community welfare.

Fourthly, Achebe's explanation of Igbo traditional cultural values lays emphasis on the need for the contemporary Nigerian leadership to recognize the utility of Igbo traditional wisdom and the possibility of its application in the assessment of current experiences and problems of Igbo ethnic group in Nigeria. This is because; we still have people like the fictional Nwaka and Ezeidemili in AG in Igbo community today who will always use their position to subvert truth because of jealousy and personal ambition. Similarly, there still exists in many parts of Igbo community where the long and unending land dispute like the one between the fictional Umuaro and Okperi clan, rears its ugly head resulting in war and destruction of both human and materials that run into millions of naira. This is usually happens because those in position of authority refuse to agree on the principle and mode of settlement owing to personal ego and refusal to accept the truth because it was uttered by an "enemy.”

Fifthly, Achebe's portrayal of Ezeulu as having abused the powers vested in him as the chief priest of Ulu deity is not far from what is happening in Nigeria today, where elected representatives of the people display arrogance and disregard for the welfare of the people, who put them in position of authority. In Achebe's view, Ezeulu's double role as the powerful intermediary for the people as well as servant of Ulu deity need not be at variance if he adequately understands and recognizes his power, for the fact that Ulu belongs to and functions for the benefit and protection of the community, the chief priest is automatically both the servant of the deity and the people. He maintains communal role of balancing societal peace, prosperity and moral transparency. In fact, there is an existing ontological link that bonds him to the community.

However, the Igbo man's sense of dynamism in his attitude to life and reality is strongly exposed by Achebe in the fictional Ezeulu's acceptance of mutability as a constant inevitable historical absolute, which every Igbo man reckons with. It is on this account that Ezeulu sent one of his sons, Oduche to school to learn the white man's ways. For he admonishes the young lad "if any one ask you why you should be sent to go and learn these new things, tell him that a man must dance the dance prevalent in his time” (370). This is in consonance with the metaphorical adage he earlier used to admonish the same Oduche in chapter four when he reiterates: "the world is like a mask dancing, if you want to see it well you do not stand in one place” (390).

In conclusion, it should be emphasized that one of the preoccupations of Achebe in AG is to expose the inevitable consequences of a situation where those in position of power and authority forget the derivative source of their power (the people) and rather cling to individual inclination and personal aggrandizement. This definitely, brings them down from grace to grass. As far as Achebe is concerned, he would be quite satisfied if his novels (especially Arrow of God which was set in the past) did no more than teach his readers that "their past with all its imperfections was not one long night of savagery from which the first European acting on God's behalf delivered them.” Achebe C. (1988:30), Okolo (2007: p. 53). Similarly, Gikandi (1991: p. 202) remarks that “Achebe's novels ... are among the works that tried to rehabilitate the identity and history of African character, 
to assert the validity of African culture, and to expose the violence which colonial domination had brought to bear on African societies.”

Achebe's AG has revealed that there is indeed a great repository of oral and pre-literary tradition which our forebears have left behind for us to transmit to other generations as well as use as the moral-social pedestal and foundation for engineering new paradigm structures for internally motivated African development. Such is the template Achebe tried to expose in AG; an Igbo primordial and communal value system that defines his personality and determine his effectiveness as a creative moral citizen of his community. This is in line with the assertion of Ike Obiora (2001: p. 34) that "a deeper understanding of the African culture and its people will ultimately breed a profound respect for, and embrace of, African traditional values, which, when properly understood reveal to the discerning mind a wisdom of the ages capable of providing some solutions to our contemporary search for sustainable development and a peaceful, equitable society.” There is the need to harness the innovative potentials in Igbo traditional societies and cultures with a view to effecting a sustainable and self-reliant development of modern Igbo communities. The challenge of the contemporary Igbo lies in searching for appropriate paradigms and expressions as to define and evaluate the traditional cultural, social, ethical and religious conditions relevant to modern Igbo (African) societies.

\section{References}

Abiola, I. (1968). The Criticism of Modern African Literature. In C. Heywood (Ed), Perspectives on African Literature, London: Heinemann.

Agada, J. O. J. (2008). Influence of Igbo Metaphysic on the Writing of Things Fall Apart. Philosophy Africana, 11, 45-60.

Alumona, V. S. (2003). Culture and Societal Institutions in Chinua Acbebe’s Things Fall Apart: A Critical Reading. The International Journal of Humanity (Zomba), 17, Department of Philosophy, Chancellor College Zomba Malawi, 62-81.

Ani Casmir, K. C., Ome, E., \& Nwankwo, A. (2014). Reexamination of Igbo Value System and Igbo Parsonalty: A Kantian and African Comparative Perspective. Open Journal of Philosophy, 4, 397-403. http://dx.doi.org/10.4236/ojpp.2014.43043

Animalu, A. O. E. (1990). A Way of Life in the Modern Scientific Age, Ahiajoku Lecture. Owerri: Culture Division Ministry of Information.

Basden, G. T. (1938). The Niger Igbos. London: Seely Associates.

Echeruo, M. (1975). Chinua Achebe. In K. Bruce, \& O. Kolawole (Ed.), A Celebration of Black and African Writings (pp. 223-236), Zaria: ABU Press.

Gikandi, S. (1991). Literature in Africa 1960-90. Africa Today (2nd ed.). London: Africa Book.

Green, M. (1964). Ibo Village Affairs. London: Frank Cass.

Ifemesia, C. (1979). Traditional Humane Living among the Igbo: A Historical Perspective. Enugu: Fourth Dimension Pub.

Kalu, A. C. (2004). The Priest/Artist Tradition in Arrow of God. In: E. N. Emenyeonu (Ed.), Emerging Perspectives on Chinua Achebe, Vol. 1. Omenka: The Master Artist (pp. 195-206), Trento, NJ: African World Press INC.

Nwoye, C. M. A. (2011). Igbo Cultural and Religious Worldview; An Insider Perspective. International Journal of Sociology and Anthropology, 3, 304-317. http://www.academicjournals.org/IJSA

Obiora, I. F., \& Edozie, N. N. (2001). Understanding Africa: Traditional Legal Reasoning Jurisprudence \& Justice in Igbo Land as a Basis for Culturally Rooted and Sustainable Development. Enugu: CIDJAP PUB.

Ojinmah, U. (2004). The Man Behind the Priest. In E. N. Emenyeonu (Ed.), Emerging Perspectives on Chinua Achebe Vol. 1. Omenka: The Master Artist (pp. 207-216), Trento, NJ: African World Press INC.

Okafor, C. (2004). Igbo Cosmology and the Parameters of Individual Accomplishment in Things Fall Apart. In E. N. Emenyeonu (Ed.), Emerging Perspectives on Chinua Achebe, Vol. 1. Omenka: The Master Artist (pp. 85-96). Trento, NJ: African World Press INC.

Okafor, F. U. (1992). Igbo Philosophy of Law. Enugu: Fourth Dimension Pub.

Okolo, M. S. C. (2007). African Literature as Political Philosophy. London: CODESRIA Books Dakar in association with Zeb Books.

Okonkwo, N. C. (1996). Time, Number, Man and Deity: Igbo Civilization in Chinua Achebe’s Arrow of God. In E. Ihekweazu (Ed.), Eagle on Iroko Selected Papers from the Chinua Achebe International Symposium 1990 (pp. 105-123). Ibadan: Heinemann.

Ola, V. U. (1996) The Conflict of Genius and Discipline in Arrow of God. In E. Ihekweazu (Ed.), Eagle on Iroko Selected Papers from the Chinua Achebe International Symposium 1990 (pp. 95-104). Ibadan: Heinemann. 
Ola, V. U. (2004). The Tragic Muse and the Cultural Hero: Acbebe’s Art in Arrow of God. In E. N. Emenyeonu (Ed.), Emerging Perspectives on Chinua Achebe Vol. 1. Omenka: The Master Artist (pp. 217-228). Trento, NJ: African World Press INC.

Onyibor, M. I. S. (2012). Death in Igbo Cosmology: A Hermeneutical Investigation. Unpublished Ph.D Thesis, Nnamdi Azikiwe University, Awka.

Povey, J. (1971). The Novels of Chinua Achebe. In B. King (Ed.), Introduction to Nigerian Literature (pp. 25-37). Lagos: University of Lagos and Evan Brothers Ltd.

Uchendu, V. C. (1965). The Igbo Southeast of Nigeria. New York: Holt Rinehart \& Co.

Umezinwa, W. (1996). Vector Quantities in Chinua Achebe’s Novels. In E. Ihekweazu (Ed.), Eagle on Iroko Selected Papers from the Chinua Achebe International Symposium 1990 (pp. 124-136). Ibadan: Heinemann. 